GlasgefaBen studient werden. Bei $0-15^{\circ}$ tritt sie am deutlichsten auf. Bei dieser Temperatur tritt in den Lơsungen, die weniger als ein Prozent reiner Gelatine enthalten, ein Gerinnungsvorgang ein, der die Trennung von suspendierten, opalisierenden Flocken in einer klaren Flissigkeit herbeifuhrt. Durch Erniedrigung der Temperatur wird der Vorgang begünstigt und durch mäBiges Rühren der Flussigkeit beschleunigt. Im Gegensatz $z u$ einer Annahme von Nasse (1889) bildet auch die vollkommen gereinigte Gelatine das Gel, aber weniger gut als in Gegenwart von Elektrolyten. Spuren von Alkali, Säuren, verschiedenen Salzen, sogar KJ, oder Gelatineasche begünstigen das Erstamen.

E. $M$.

\title{
Arbeiten über Methoden, Apparate und Analyse.
}

Dhéré, Ch., und Gorgolewski, M. Ueber die Erlangung eines an Elcktrolyten äuBerst armen Serums durch elektrische Dialyse. (Compt. rend. 150, $993996,1910$.

In ein $U$-Rohr aus Jenenser Glas wird ein durch gewöhnliche Dialyse bereils weitgehend von Elektrofyten befreites Serum gebracht und nach Verschlu日 der Schenkel mit Kollodiummembranen einem elektrischen Felde ausgesetzt, indem jeder Schenkel in ein mit Platinelektrode versehenes und mit Leitfahig. keilswasset gefulltes GefäB taucht. Die im Serum noch vorhandenen Elektrolyte reichern sich dabei in diesem Wasser an, das öfter erneuert wird. Der Vorgang wird als "elektrische Dialyse" bezeichnet. Die Albuminoide beteiligen sich an dem elektrischen Transport nut in verschwindendem Maße. Durch gewohnliche Dialyse vermochte man bislang nur ein Scrum von der Leilfahigkeit von $28 \times 10^{-\mathrm{i}}$ bei einer Konzentration der Albuminoide von $15 \mathrm{~g}$ im Liter zu erzielen, wathrend mit dieser Methode die Reinigung bis $2 u$ einer Leitfahigkeit von $7,6 \times 10^{-6}$ getrieben worden ist. Diese Albuminoide haben also eine spezifische Leitfahigkeit von derselben GröBenordnung wie die reinsten anotganischen Kolloide. Ein Serum von der Leitthigkeit $91<10^{-6}$ wird auf $Z$ usatz von Alkohol oder bei der Siedetemperatur stark milchig, oline zu flocken, wogegen das elektrisch vollkommen dialysierte auch bei Zusatz geringster Mengen von Alkohol in Flocken koaguliert, die bei Abwesenheit von Elektrolyten nicht wieder in Wasser gelost werden konnen. Besonders bemerkenswert ist, dab das reine Serum nichi nur bei einer weit unter dem Siedepunkt liegenden Temperatur in groben Flocken jerinnt, sondern schon bei $44^{\circ}$ selir deutlich trübe wird. wenn man es 15 Minuten bei diescr Temperatur hält; diese Tuubung tüht von einer teilweisen Gerinnung her und ist nicht beständig, sondein geht nach einiger Zeit in eine Ausflockung uber.

\section{Arbeiten über Mineralogie und Agrikulturchemie.}

Van der Leeden, R.. Ueber das Verhalten der Feldspatresttone und der Allophantone gegen Essigsalure. (Zentralbl. f. Mineralogie, Geologie und $\mathrm{Pa}$ là่ากt. 1910, 289-245.)

Es wird Allophan von Ohio im Vergleiche zu Kaolin von Zattlitz, au seine Löslichkeit in Essigsäure untersucht. Die Löslichkeiten sind so verschieden, daB sie als Unterscheidungsmittel der beiden Substanzen angewaridt werden können. Fs wurde eine sechs- und eine zwôfprozentige Essigsäure in einer elektrischen Schüttelmaschine angewandt. Die Loslitchkeit der Allophantone ist cine weit höhere. Von Kaolin waren 0,2 Proz. $\mathrm{SiO}_{2}$ und 0,2 Proz. $\mathrm{Al}_{2} \mathrm{O}_{3}$, beim Allophan 3 Proz. $\mathrm{SiO}_{2}$ und 7 Proz. $\mathrm{Al}_{2} \mathrm{O}_{3}$ in Losung gegangen. Beim Kaolin ist im essigsauren Auszug $\mathrm{Al}_{2} \mathrm{O}_{3}$ und $\mathrm{SiO}_{2}$ im Verhaltnisse $1: 1$, während im Minerale das Verhaltnis $1: 2$ herrscht. Beim essigsauren Auszuge des Allophans ist das Verhaltnis $\mathrm{Al}_{2} \mathrm{O}_{3} 2 \mathrm{MiO} \mathrm{SiO}_{2} \quad 1: 0,7$, das ist im selben Verhältnisse, als sie in dem angewandten Allophane stehen.

Leitmeier.

Gilpin, 1.E., und Cram, M. P., The fractionation of crude petroleum by capiliary diffusion. (Depatment of the interior U. S. Geological Survey, Bulletin 1908, 365.)

Die Verfasser kommen zu folgenden SchluBtolgerungen :

1. Wenn Petroleum in einem mit Walkerde gefiulten Rohr aufsteigt, so findet eine deutliche Trennung des Oeles in verschiedene Teile stat, wobei die Oelmenge an der Spitze des Rohres niedrigeres speziftsches Crewichl zeigt, als am Boden.

2. Wenn Wasser $2 u$ peiroleumhaltiger Waikerde gegeben wird, so unters, heidet sich das zuerst durch
Wasser verdrängte Erdöl in seinem spezifischen Gewicht von dem spater bei Zusatz giöBerer Wassermengen verdrängten.

3. In dem unter 1. dargestellten Fall sammeln sich die Kohlenwasserstoffe der Paraffinreihe in dem an der Spitze befindlichen, das geringste spezifische Gewicht aufweiscnden Teil, die ungesăttigten Kohlenwasscrstoffe dagegen unten.

4. Mit Erdöl gemisctste Walkerde hălt bei Verdrängung des Oels mit Wasser ungefähr ein Drittel des Oels zurick. Ehrenberg (Hann. Münden).

Hissink, Dr. D. J., Die kolloiden Stoffe"im Boden und ihre Bestimmung. (Vorirag gehalten auf der 11. internationalen agrogeologischen Konferenz in Stockholm, August 1910.)

Die Bodenkolloide sind von grofer Bedeutung für die Fruchtbarkeit des Bodens. Es ist daher wichtig, die kolloiden Stoffe im Boden zu bestimmen. Mittelst der Schlämmanalyse ist eine Trennung in Kolloide und mineralische Bestandicile nicht möglich, da bei der Schlämmung sehr kleine mineralische Partikelchen vom strömenden Wasser mitgefülırt werden konnen, während andrerseits Sand kolloider Natur zuriickbleiben kann. F. Cornu hat auf die Färbungsmethode aufmerksam gemacht. Mittelst Fuchsiufarbung cincr Bodenprobe kann man sich in Kürze uberzeugen, welche ungefähren Mengen von Kolloidsubsianzen überhaupt in der Probe enthalien sind, indem fasi stirutliche Bodenkolloide als stark basophile Körpet eine sch warzrote Farbung annehmen. Sjollema versuchte mittels zentrifugieren die Kolloidsubstanzen des Bodens von den Mineralfragmenten und Quarzkörnem zu trennen. Eine chemische Wethode zur Ermittelung der Menge und 7 usammensetzung des kolloiden Bodenkomplexes 